\title{
ABSURDITAS DALAM PUISI DERAI-DERAI CEMARA KARYA CHAIRIL ANWAR
}

\author{
Muhammad Husni \\ Universitas Indonesia \\ Email: muhammad.husni81@ui.ac.id
}

\begin{abstract}
Abstrak: Absurditas merupakan hubungan antara alam batin manusia dan alam dunia nyata, baik yang bersifat harmonis maupun disharmorni, yang potensial menjadi sumber inspirasi penulisnya. Penelitian ini bertujuan untuk mengetahui absurditas dalam puisi Derai-Derai Cemara karya Chairil Anwar. Artikel ini dianalisis menggunakan metode deskriptif kualitatif. Pengumpulan data dilakukan melalui analisis dokumen secara kritis. Teori absurditas yang dimaksud dalam penelitian ini ialah absurdisme yang dipopulerkan oleh Albert Camus. Hasil temuan dalam penelitian ini menunjukkan puisi Derai-Derai Cemara karya Chairil Anwar mengandung nilai-nilai absurditas. Absurditas tersebut ialah pemaknaan hidup, keterasingan, harapan, dan pemberontakan. Dalam puisi Derai-Derai Cemara, Chairil Anwar memberikan pandangannya bahwa "hidup hanya menunda kekalahan." Dari hasil analisis tersebut dapat disimpulkan bahwa puisi ini menggambarkan usaha seorang manusia menjalani hidup yang absurd tanpa jalan yang pasti.
\end{abstract}

Kata Kunci: absurditas, albert camus, chairil anwar, derai-derai cemara, puisi

\section{ABSURDITY IN THE POETRY OF DERAI-DERAI CEMARA BY CHAIRIL ANWAR}

\begin{abstract}
Absurdity is the relationship between the inner nature of humans and the real world, both harmonious and disharmonious which is often a source of inspiration for the author. This study aims to find out the absurdity in the poem Derai-Derai Cemara by Chairil Anwar. This article was analyzed using a qualitative-descriptive method. Data collection is done through critical document analysis. The theory of absurdity referred to in this study is the absurdism popularized by Albert Camus. The findings in this study show that the poem Derai-Derai Cemara by Chairil Anwar contains values of absurdity. The absurdity is the meaning of life, alienation, hope, and rebellion. In the poem Derai-Derai Cemara, Chairil Anwar gives his view that "life is but postponement of defeat.". From the results of the analysis, it can be concluded that this poem describes the effort of a human being to live an absurd life without a definite path.
\end{abstract}

Keywords: absurdity, albert camus, chairil anwar, derai-derai cemara, poetry.

\section{PENDAHULUAN}

Absurditas adalah suatu episode dalam kehidupan manusia yang merupakan hasil analisis manusia terhadap kehidupan. Absurditas hadir sebagai dampak hubungan antara alam batin manusia dengan realita di dunia nyata. Manusia yang menerima dan menguasai keabsurdan yang hadir dalam diri mereka dapat menentukan jalan hidup serta menghidupinya meskipun diri mereka merasa asing 
terhadap permasalahan tersebut. Akan tetapi, manusia yang tidak dapat mengerti bahkan menerima keabsurdan dalam diri akan mengakhiri hidup dengan jalan pintas yaitu bunuh diri (Fitri, 2013: 1). Berbagai perasaan kesal, bimbang, ingin melawan keadaan, dan perasaan lain yang sulit dijelaskan secara rasional yang bercampur memberi afirmasi bahwa kehidupan serta eksistensinya adalah sebuah kesia-siaan.

Di Indonesia banyak hadir sastrawan yang beraliran absurd, antara lain, Iwan Simatupang, Putu Wijaya, dan Asneli Lutan. Jakob Sumardjo, seorang kritikus sastra, pernah mengangkat dua nama sastrawan beraliran absurd dalam bukunya Pengantar Novel Indonesia yang menekuni bidang prosa yakni, Putu Wijaya dan Asneli Lutan. Jakob mengatakan bahwa Putu Wijaya memiliki gaya tulisan yang mirip dengan fiksi absurd yang ada di Barat (Sumardjo, 1991: 108).

Untuk menangkap nilai-nilai absurd dari sebuah karya sastra di bidang prosa dan drama lebih mudah untuk dilakukan dibandingkan di bidang puisi. Hipotesis ini dibuktikan dengan bertebarannya jurnal-jurnal yang membahas absurditas di karya sastra di luar puisi seperti penelitian yang dilakukan Yusriansyah dalam "Absurditas Naskah Drama 'Pelajaran' karya Eugene Ionesco" (2019), Oktiva dalam "Analisis Absurditas Surrealisme dalam Roman Villa Triste karya Patrick Modiano" (2018), Utami dalam "Absurditas dalam Novel Sampar karya Albert Camus" (2018), dan Fitri dan Wahyudi dalam "Absurditas dalam Cerpen-Cerpen Asneli Lutan" (2013).

Puisi dapat dipahami sebagai bentuk pengucapan gagasan yang bersifat emosional dengan mempertimbangkan efek keindahan. Hal tersebut dapat terjadi sebab puisi merupakan jelmaan dari perasaan dan cita rasa penyair tersebut. Ekspresi seorang penyair ini akan bernilai sastra jika mampu diungkapkan dalam bentuk bahasa yang cermat dan tepat. Dengan kata lain, puisi hendaknya mengemukakan kritik tentang kehidupan. Lebih lagi, puisi adalah bentuk karya sastra yang mengungkapkan pikiran dan perasaan penyair secara imajinatif dan disusun dengan semua kekuatan bahasa dengan pengonsentrasian struktur fisik dan struktur batinnya (Adhitya, 2013: 2).

Kata puisi secara etimologi memiliki akar dari bahasa Yunani yakni poemia, yang berarti membuat; poeites yang berarti pembuat, pembangun atau pembentuk. Dalam bahasa Inggris kata puisi disebut dengan poem atau poetry (Aminuddin, 2002: 134). Puisi diartikan "membuat" dan "pembuat" karena lewat puisi pada dasarnya seseorang telah menciptakan dunia tersendiri yang mungkin berisi pesan atau gambaran suasana tertentu, baik fisik maupun batiniah.

Albetrend dalam Pradopo (1990) mengungkapkan bahwa puisi adalah pertunjukan pengalaman yang 
bersifat penafsiran dalam bahasa yang berirama. Hal ini selaras dengan pernyataan Coleridge bahwa puisi adalah kata-kata yang terindah dalam susunan yang terindah. Kedua pandangan tersebut kemudian dilengkapi oleh Pradopo, "puisi merupakan ekspresi pemikiran yang membangkitkan perasaan, yang merangsang imajinasi panca indera dalam susunan yang berirama" (Pradopo, 1990: 5-7). Berangkat dari anggapan-anggapan di atas, dapat ditarik sebuah kesimpulan yakni puisi adalah ekspresi gagasan dengan katakata indah yang merangsang perasaan, imajinasi, serta pancaindra dalam susunan yang berirama.

Puisi yang disusun dan hadir dari penjiwaan seorang penyair, membentuk konfigurasi kalimat yang acap melibatkan manusia, hewan bahkan makhluk yang lainnya-baik secara abstrak maupun nyata-yang sarat akan nilai (Keraf, 2009: 105). Hal ini merupakan gambaran tentang bagaimana proses pemanfaatan sebuah karya terhadap objek makhluk hidup. Dari sana kita diperlihatkan mengenai betapa uniknya karya-karya sastra, terutama puisi, yang hadir tidak hanya sebagai karya yang alih-alih hanya dapat menghibur melainkan mampu menegur tindakan-tindakan manusia yang menyimpang serta mengajarkan arti kehidupan.

Dalam salah satu disiplin ilmu filsafat ada sebuah paham beraliran eksistensialisme bernama absurdisme.
Konsep Absurdisme dipopulerkan oleh Albert Camus dalam karangannya yang berjudul Mite Sisifus. Dalam buku itu diceritakan bahwa Sisifus diberi hukuman oleh para dewa, hukuman yang harus ia laksanakan yaitu mengangkat sebuah batu besar ke puncak gunung yang memiliki permukaan terjal. Namun, setelah mengangkat batu tersebut ke atas gunung, batu itu akan menggelinding kembali ke bawah, kemudian Sisifus harus mengangkut batu tersebut kembali ke puncak (Sumiyadi, 2010: 3). Goenawan Mohamad dalam Catatan Pinggir menuliskan, "dalam dongeng ini, menurut tafsiran Albert Camus sejarah manusia berlangsung mengasyikkan tapi di ujungnya harapan besar apa pun tak akan terpenuhi." (Mohamad, 1982: 201).

Topik-topik yang menjadi bahan telaah aliran absurd antara lain, kesejarahan, pertentangan, keterasingan, penderitaan, kegagalan, kegalauan, kecemasan, dan kematian (Werdiningsih, 2013: 56). Absurditas tergambar sebagai buah hubungan antara alam batin manusia dan alam dunia nyata. Manusia yang menyambut dan menaklukkan keabsurdan yang hadir dalam kehidupan ini dapat menentukan jalan hidup serta menghidupinya meskipun diri mereka merasa asing terhadap permasalahan tersebut (Fitri, 2013: 14). Namun, apabila yang terjadi adalah sebaliknya, maka manusia tersebut akan 
mengakhiri hidup dengan jalan pintas yakni bunuh diri.

Albert Camus memberikan pernyataan bahwa bunuh diri adalah sebuah bentuk pengakuan dari seseorang apabila dia telah dikalahkan dan/atau tidak mengerti kehidupan (Camus, 1999: 6). Bunuh diri dianggap sebagai jalan keluar paling instan untuk mengakhiri segala penderitaan dan absurditas dalam kehidupan. Secara hakiki dunia ini dipenuhi absurditas, ada banyak jenis kebenaran akan tetapi tidak ada satu pun yang mendekati kesempurnaan. Sebuah hal paradoksal yang tidak peduli kita menerimanya atau tidak, akan tetap terjadi sebagaimana hukum alam. Hukumhukum alam pada asasnya memiliki keterbatasan untuk berlaku, ketika hal itu berbalik melawan dirinya sendiri maka lahirlah absurditas.

Periode 1942-1949 adalah fase aktif dan melanglang buana seorang penyair Indonesia bernama Chairil Anwar. Pada kehidupan sastra Indonesia, dia awam dikenal sebagai pelopor Angkatan 45 dengan julukannya "Si Binatang Jalang" merujuk dari salah satu puisinya yang berjudul "Aku". Dalam kehidupan sastra, dia menjadi agen pembawa perubahan sosio-kultural, yang melalui puisi-puisinya melekatkan konsep kebebasan individual dan absurditas berbalut modernisme ke dalam hati dan pikiran para penikmat karyanya (Setyawan, 2019: 348). Dengan penuh keyakinan, penulis dapat menyatakan bahwasanya pembahasan mengenai
Chairil Anwar baik tentang kehidupan maupun karyanya sudah banyak dilakukan.

Namun, penelitian terhadap puisi yang berjudul Derai-Derai Cemara karya Chairil Anwar dari sudut pandang Absurdisme belum pernah dilakukan sebelumnya. Pada berbagai media, baik cetak maupun dalam jaringan (daring) terdapat beberapa penelitian yang pernah diadakan, membahas karya-karyanya melalui metodologi semiotika. Untuk memperkaya referensi penelitian, telah dilakukan tinjauan pustaka terhadap beberapa penelitian sebelumnya mengenai Chairil Anwar dari berbagai disiplin ilmu serta berbagai penelitian penerapan konsep absurdisme dalam bidang sastra seperti yang tertera di atas. Penelitian ini bertujuan menghasilkan analisis, yang bersifat tekstual, yang menunjukan adanya perwujudan absurditas dan eksistensialisme, terutama yang berkenaan dengan kematian dalam puisi Derai-Derai Cemara karya Chairil Anwar.

\section{METODE}

Dalam artikel ini, analisis karya sastra dilakukan dengan metode deskriptif kualitatif melalui tokoh yang menekuni bidang puisi bernama Chairil Anwar dan bertujuan menjelaskan absurditas yang terdapat dalam karyanya. Dari 75 sajak asli dan 2 sajak saduran karya Chairil Anwar di dalam buku "Aku Ini Binatang Jalang" pilihan dijatuhkan pada karyanya yang ditulis 
pada tahun 1949 berjudul Derai-Derai Cemara sebab dinilai mampu menyoroti nilai-nilai yang bertolak daripada vitalitas sebagaimana yang selalu ditunjukan Chairil Anwar dan menunjukkan penerimaannya akan absurditas kehidupan dan realita bahwa "hidup hanya menunda kekalahan." (Anwar, 2011: 103).

Subjek dalam penelitian ini adalah puisi Derai-Derai Cemara karya Chairil Anwar yang diterbitkan ulang oleh Gramedia pada tahun 2011 dalam antologi setebal 131 halaman. Objek dalam penelitian ini adalah absurditas yang meliputi manusia dan penderitaan, manusia dan tanggung jawab, manusia dan keterasingan, serta manusia dan harapan (Utami, 2018: 4). Dalam analisis, digunakan teori strukturalisme-semiotik dan teori absurditas Albert Camus. Pada penelitian tentang absurditas dalam puisi Derai-Derai Cemara karya Chairil Anwar digunakan metode deskriptif kualitatif yang menjelaskan hasil temuan berdasarkan karya sastra.

Menganalisis sebuah karya sastra melalui teori strukturalisme berarti mengkaji seluruh unsur yang termaktub dalam sebuah karya sastra. Semua unsur tersebut saling berhubungan erat, dan tiap-tiap unsur dalam situasi tertentu terkadang tidak memiliki makna dengan sendirinya, melainkan bergantung pada hubungannya dengan unsur lain yang terlibat. Pemaknaan penuh dari suatu pengalaman hanya dapat dimengerti jika koheren dalam struktur yang berposisi sebagai keseluruhan dari tiap satuan tersebut (Hawkes dalam Pradopo, 1995: 142). Unsur-unsur dalam puisi, yang biasa disebut sebagai sarana kepuitisan, di antaranya adalah bahasa kiasan yang terdiri dari majas dan retorika. Sarana kepuitisan memiliki nilai yang harus dijelaskan melalui analisis semiotik.

Analisis semiotik adalah memproduksi secara eksplisit kata-kata yang mulanya dalam sebuah puisi sehingga memiliki makna (Pradopo, 1995: 143). Suatu unsur dalam puisi mempunyai nilai dalam hubungannya pada unsur lain maupun struktur puisi secara keseluruhan. Oleh karena itu, struktur sebuah puisi harus dikaji, dan unsur-unsurnya yang merupakan tanda-tanda yang bernilai di dalamnya harus dijelaskan. Kemudian, menjadi jelas bahwasanya untuk mengkaji puisi, analisis semiotik tidak dapat dijauhkan dengan analisis struktural.

Ratna (2008: 47) memberikan pernyataan bahwasanya metode kualitatif memberikan penekanan terhadap data alamiah dalam kaitannya dengan hal kehadirannya. Dalam konteks ini, data alamiah yang dituju adalah teks karya sastra berupa puisi. Noor (2007: 70) berpandangan "dalam penelitian teks karya sastra fokus untuk dianalisis adalah teks, setelahnya kalau faktor pengarang atau pembaca hanya ditekankan sebagai hal komplementer." Salah satu dari ciri pendekatan kualitatif menurut Endraswara (2003: 
5) ialah bagaimana manusia berperan sebagai instrumen utama dalam penelitian sebagaimana dituliskan oleh Nasution (dalam Sugiyono, 2015: 223) "Dalam penelitian kualitatif tidak ada pilihan lain daripada menjadikan manusia sebagai instrumen penelitian utama. Alasannya ialah bahwa segala sesuatunya belum mempunyai bentuk yang pasti. Masalah, fokus penelitian, prosedur penelitian, hipotesis yang digunakan, bahkan hasil yang diharapkan, itu semua tidak dapat ditentukan secara pasti dan jelas sebelumnya. Segala sesuatu masih perlu dikembangkan sepanjang penelitian itu. Dalam keadaan yang serba tidak pasti dan tidak jelas itu tidak ada pilihan lain dan hanya peneliti itu sendiri sebagai alat satu-satunya yang dapat mencapainya."

Penelitian sebagai serangkaian kegiatan ilmiah wajib dilakukan secara sistematis. Oleh karena itu, penelitian dirancang dan dilaksanakan secara bertahap mulai dari tahap perumusan masalah hingga tahap penulisan hasil temuan. Secara umum, tahapan penelitian terbagi menjadi tiga yaitu, persiapan, pelaksanaan, dan penyelesaian. Pada tahap persiapan, penelitian dimulai dengan perumusan topik, tesis, dan judul; konsultasi dengan pihak pembimbing; serta proses memutuskan pertanyaan penelitian dan indikator dalam penelitian. Kemudian, penelitian dilanjutkan dengan melaksanakan tinjauan pustaka pada penelitian yang pernah diadakan dan sumber-sumber yang berkaitan dengan judul dan pokok masalah.
Tahap kedua dalam penelitian merupakan tahap pelaksanaan dan menjadi tahap yang paling penting. Tahapan ini berksisar pada proses pengumpulan data, pengkajian data, dan menyimpulkan hasil temuan. Tahap ketiga atau yang terakhir adalah penyelesaian, berkaitan dengan proses merangkai laporan hingga tahap penyerahan laporan. Penulisan laporan dilakukan secara sistematis mulai dari pendahuluan hingga kesimpulan (Utami, 2018: 6).

Hasil dari penelitian ini hendak ditujukan guna mendeskripsikan konsep-konsep absurditas dalam puisi Derai-Derai Cemara karya Chairil Anwar. Oleh sebab itu data penelitian ini berupa bait-bait puisi dalam puisi Derai-Derai Cemara yang mencitrakan konsep-konsep absurditas. Data merupakan bukti-bukti yang keabsahannya bermanfaat untuk memecahkan masalah. Sudaryanto (1990: 33) berpendapat bahwa sumber data dibedakan menjadi dua yakni, substantif dan lokasional. Sumber data substantif memiliki kaitan dengan pertanyaan "dari apa?", sedangkan sumber data lokasional memiliki kaitan dengan pertanyaan "dari mana?" Sumber data substantif pada penelitian ini merupakan teks puisi, kemudian sumber data lokasional berupa sebuah antologi yang berjudul "Aku Ini Binatang Jalang" karya Chairil Anwar yang diterbitkan oleh Gramedia pada tahun 2011 dengan tebal 131 halaman dan dengan sampul berwarna kemerahan. 
Pada penelitian ini, proses pengumpulan data dilaksanakan dengan cara observasi langsung terhadap objek penelitian serta penandaan data. Akan halnya langkahlangkah yang saya lakukan, di antaranya; (1) Membaca seluruh teks dalam puisi Derai-Derai Cemara karya Chairil Anwar; (2) Membaca ulang disertai dengan pengidentifikasian calon data; (3) Mengecek kembali dibarengi dengan pencatatan dan penandaan; (4) Mengklasifikasikan data.

\section{HASIL DAN PEMBAHASAN}

\section{Absurditas dalam Puisi Derai-Derai Cemara}

Secara hakiki, puisi adalah sebuah teks yang dalam penggunaan bahasa membentuk definisi dan jalur pengekspresian jiwa yang diwujudkan dalam bentuk susunan kata atau kalimat yang sarat dengan makna. Ketika membaca sebuah puisi kita tidak jarang menemukan kata-kata yang bersifat ambigu, dengan kata lain kata-kata tersebut sarat makna dan penggunaan bahasa dalam puisi merupakan bahasa kiasan atau isyarat yang perlu dipahami oleh pembaca. Hadirnya kajian semiotika ditujukan untuk membahas secara tuntas tentang tanda-tanda, isyarat dan lambang pada sebuah karya sastra dengan tujuan memberikan kepuasaan untuk para pegiat sastra khususnya puisi (Pribadi, 2019: 272).
Pendekatan semiotika yang digunakan untuk menganalisis puisi Chairil Anwar Derai-Derai Cemara ditujukan guna mencari kepuasan batin serta untuk mengapresiasi dan jalan untuk memahami gagasan yang ingin disampaikan oleh Chairil pada puisi tersebut. Chairil Anwar merupakan seorang penyair dan penulis termasyhur yang seluruh karyanya dapat dinikmati oleh kalangan lintas zaman dan dapat diklasifikasikan sebagai hipogram. Oleh sebab itu mengkaji puisinya menggunakan pendekatan semiotika merupakan sebuah tantangan yang menarik.

Bentuk utuh puisi seperti berikut ini:

\section{Derai-Derai Cemara \\ Cemara menderai sampai jauh terasa hari akan menjadi malam \\ ada beberapa dahan di tingkap merapuh \\ dipukul angin yang terpendam}

Aku sekarang orangnya bisa tahan

sudah berapa waktu bukan

kanak lagi

tapi dulu memang ada suatu

bahan

yang bukan dasar perhitungan

kini

Hidup hanya menunda

kekalahan

tambah terasing dari cinta

sekolah rendah

dan tahu, ada yang tetap tidak

diucapkan

sebelum pada akhirnya kita

menyerah 


\section{Penciptaan Makna pada Puisi Derai- Derai Cemara}

Dalam proses penciptaan makna atau pemaknaan sebuah puisi, sebuah kata yang mempunyai arti sesungguhnya (denotasi) akan berubah menjadi kata yang memiliki arti yang bukan sesungguhnya (konotasi). Pada proses pemaknaan ini pula, tidak jarang seorang penyair memilih diksi yang jarang digunakan oleh awam, dari pilihan-pilihan kata tersebut sebuah puisi menjadi indah dan kaya akan makna. Ketika Chairil menciptakan puisi Derai-Derai Cemara ini dapat ditemukan beberapa pengulangan bunyi, rangkaian pengulangan bunyi itu memberikan bunyi efoni, efoni yaitu gabungan bunyi yang merdu dan indah (Pradopo, 2012: 14).

Puisi ini disajikan dengan diksi yang sederhana sehingga para pembacanya mudah mengerti serta turut menghayati apa yang dialami oleh Chairil. Sarana kepuitisan dalam bentuk majas di puisi ini yang dapat ditangkap dengan jelas ada 3 macam, yaitu hiperbola, personifikasi, dan alegori. Hasil temuan akan disajikan pada tabel 1 berikut.

Tabel 1. Jenis Majas

\begin{tabular}{ccc}
\hline $\begin{array}{c}\text { Jenis } \\
\text { Majas }\end{array}$ & Lirik & $\begin{array}{c}\text { Bait/ } \\
\text { Larik }\end{array}$ \\
\hline Hiperbola & $\begin{array}{c}\text { Cemara menderai sampai } \\
\text { jauh }\end{array}$ & $1 / 1$ \\
\hline $\begin{array}{c}\text { Personifi } \\
\text { kasi }\end{array}$ & $\begin{array}{c}\text { Dipukul angin yang } \\
\text { terpendam }\end{array}$ & $1 / 4$ \\
\hline Alegori & $\begin{array}{c}\text { Terasa hari akan menjadi } \\
\text { malam }\end{array}$ & $1 / 2$ \\
\hline
\end{tabular}

\begin{tabular}{|c|c|}
\hline $\begin{array}{c}\text { Ada beberapa dahan di } \\
\text { tingkap merapuh }\end{array}$ & $1 / 3$ \\
\hline $\begin{array}{c}\text { Aku sekarang orangnya bisa } \\
\text { tahan }\end{array}$ & $2 / 1$ \\
\hline $\begin{array}{c}\text { Sudah beberapa waktu bukan } \\
\text { kanak lagi }\end{array}$ & $2 / 2$ \\
\hline $\begin{array}{c}\text { Tapi dulu memang ada suatu } \\
\text { bahan }\end{array}$ & $2 / 3$ \\
\hline $\begin{array}{l}\text { Yang bukan dasar } \\
\text { perhitungan kini }\end{array}$ & $2 / 4$ \\
\hline $\begin{array}{c}\text { Hidup hanya menunda } \\
\text { kekalahan }\end{array}$ & $3 / 1$ \\
\hline $\begin{array}{c}\text { Tambah terasing dari cinta } \\
\text { sekolah rendah }\end{array}$ & $3 / 2$ \\
\hline $\begin{array}{c}\text { Dan tahu, tetap ada yang } \\
\text { tidak terucapkan }\end{array}$ & $3 / 3$ \\
\hline $\begin{array}{c}\text { Sebelum pada akhirnya kita } \\
\text { menyerah }\end{array}$ & $3 / 4$ \\
\hline
\end{tabular}

Puisi ini disusun dengan kukuh, tiap bait terdiri dari empat larik yang di dalamnya menggunakan rima $a-b-a-b$. Citraan alam yang diterapkan Chairil menimbulkan kesan tenang, suara derai-derai yang hadir dari pepohonan cemara yang mampu terdengar sampai hingga kejauhan dan menyiratkan pergantian waktu, yakni hari segera berganti malam.

\section{Pergantian Makna pada Puisi Derai- Derai Cemara}

Dalam bait pertama, "cemara menderai sampai jauh" memiliki makna akan sebuah proses kehidupan yang telah berjalan dan melalui rangkaian yang panjang sehingga waktu, "hari," terus berganti, "menjadi malam," dan dihadapkan pada posisi tidak dapat melawan. Mau tidak mau usia kian bertambah pula tubuh makin 
merenta, "ada beberapa dahan di tingkap merapuh." Proses panjang bernama kehidupan itu dihiasi dengan perjalanan yang keras di masa lampau, akan tetapi perasaan serta kenangan yang membekas akan hal tersebut mulai memudar, "dipukul angin yang terpendam."

Pada bait kedua, "aku sekarang orangnya bisa tahan" menyiratkan bahwa aku, dalam hal ini Chairil Anwar, telah mendapati banyak pengalaman di hidupnya dan ada di titik mampu berkompromi dengan keadaan sebab usianya yang sudah tidak lagi muda, "sudah berapa waktu bukan kanak lagi." Namun, sosok aku tersebut tidak menyangkal bahwa memiliki masalah ketika masih muda yang dikiaskan dalam "namun dulu memang ada suatu bahan" yang sekarang tidak perlu sosok aku ambil pusing dan telah melalui proses penerimaan, "yang bukan dasar pertimbangan kini."

Dari lampiran puisi di atas, dalam bait ketiga tertulis "hidup hanya menunda kekalahan" adalah sebuah adagium layaknya "hidup seribu tahun lagi." Kalimat hidup hanya menunda kekalahan memberi arti bahwa hidup yang dijalankan adalah sebuah kisah panjang yang suka atau tidak suka harus dijalankan, perlawanan tidak dapat dilakukan selamanya. Hingga, semua mewujud kian asing dan terlupakan, terutama kenangan semasa kecil, "tambah terasing dari cinta sekolah rendah." Sebagai akibat, ada suatu hal yang tidak pernah benarbenar dapat dilakukan, "dan tahu, ada yang tetap tidak terucapkan." Sosok aku menutup kisah dalam puisi ini dengan kepasrahan dan ketidakberdayaannya disebabkan tidak sanggup lagi melakukan apapun, "sebelum pada akhirnya kita menyerah".

\section{Hipogram pada Puisi Derai-Derai Cemara}

Secara pengertian, hipogram dapat dipahami sebagai latar yang diceritakan dalam sebuah karya sastra. Menurut Teeuw dalam Pribadi (2019: 273) hipogram merupakan sebuah penafsiran latar oleh pembaca. Latar yang dirujuk dapat hadir sebagai sebuah peristiwa, sejarah, tempat atau kehidupan. Puisi karangan Chairil ini mempunyai hipogramnya sendiri, Derai-Derai Cemara menceritakan sosok aku yang merasa bahwa dirinya tidak lebih dari boneka takdir. Sosok aku merasakan keterasingan dari masa lalunya di umur yang sudah mulai menua dan kepasrahan yang dalam perihal menjalani kehidupan. Di samping itu, suasana yang hendak dihadirkan dalam puisi tersebut merupakan suasana haru penyerahan yang dibarengi sebuah optimis-yang menjadikannya sebuah peristiwa absurd. 


\section{Absurditas pada Puisi Derai-Derai Cemara}

Berdasarkan hasil analisis, ditemukan data sebanyak 4 bait 12 larik yang dibagi ke dalam 4 kategori dalam konsep absurditas yakni manusia dan penderitaan (1), manusia dan tanggung jawab (2), manusia dan kegelisahan (3), serta manusia dan harapan (4). Hasil analisis disajikan dalam tabel 2 berikut.

Tabel 2. Kategori Absurditas

\begin{tabular}{|c|c|}
\hline Lirik & Kategori Absurditas \\
\hline Cemara menderai sampai jauh & $\begin{array}{l}\text { Manusia } \\
\text { kegelisahan (3) }\end{array}$ \\
\hline $\begin{array}{l}\text { terasa hari akan menjadi } \\
\text { malam }\end{array}$ & $\begin{array}{l}\text { Manusia } \\
\text { kegelisahan (3) }\end{array}$ \\
\hline $\begin{array}{l}\text { ada beberapa dahan } \quad d i \\
\text { tingkap merapuh }\end{array}$ & $\begin{array}{l}\text { Manusia } \\
\text { kegelisahan (3) }\end{array}$ \\
\hline dipukul angin yang terpendam & $\begin{array}{ll}\text { Manusia } & \text { dan } \\
\text { penderitaan (1) } & \end{array}$ \\
\hline $\begin{array}{l}\text { Aku sekarang orangnya bisa } \\
\text { tahan }\end{array}$ & $\begin{array}{l}\text { Manusia dan tanggung } \\
\text { jawab (2) }\end{array}$ \\
\hline $\begin{array}{l}\text { sudah berapa waktu bukan } \\
\text { kanak lagi }\end{array}$ & $\begin{array}{l}\text { Manusia dan tanggung } \\
\text { jawab (2) }\end{array}$ \\
\hline $\begin{array}{l}\text { tapi dulu memang ada suatu } \\
\text { bahan }\end{array}$ & $\begin{array}{ll}\text { Manusia } & \text { dan } \\
\text { kegelisahan (3) } & \end{array}$ \\
\hline $\begin{array}{l}\text { yang bukan dasar perhitungan } \\
\text { kini }\end{array}$ & $\begin{array}{l}\text { Manusia dan tanggung } \\
\text { jawab (2) }\end{array}$ \\
\hline $\begin{array}{l}\text { Hidup hanya menunda } \\
\text { kekalahan }\end{array}$ & $\begin{array}{l}\text { Manusia dan harapan } \\
\text { (4) }\end{array}$ \\
\hline $\begin{array}{l}\text { tambah terasing dari cinta } \\
\text { sekolah rendah }\end{array}$ & $\begin{array}{l}\text { Manusia dan tanggung } \\
\text { jawab (2) }\end{array}$ \\
\hline $\begin{array}{l}\text { dan tahu, ada yang tetap tidak } \\
\text { diucapkan }\end{array}$ & $\begin{array}{ll}\text { Manusia dan } \\
\text { penderitaan (1) }\end{array}$ \\
\hline $\begin{array}{l}\text { sebelum pada akhirnya kita } \\
\text { menyerah }\end{array}$ & $\begin{array}{l}\text { Manusia dan tanggung } \\
\text { jawab (2) }\end{array}$ \\
\hline
\end{tabular}

Absurditas hanya akan memiliki nilai dalam keseimbangan, konsep tersebut akan hadir dalam perbandingan, bukan dalam setiap unsur perbandingan itu. Absurditas timbul dalam proses pertemuan antara nalar efektif yang terbatas dengan irasionalitas, yang muncul pada diri manusia. Hukum-hukum alam memiliki batas-batas tertentu untuk berlaku dan di luar batas itu, hukum alam akan berbalik melawan dirinya sendiri dan melahirkan absurditas. Manusia absurd menerima dan mengakui bahwa akan selalu hadir pergulatan batin, tidak merendahkan nalar secara mutlak, dan juga mengakui ketidakrasionalan (Werdiningsih, 2013: 55).

\section{SIMPULAN}

Dalam puisi Derai-Derai Cemara, absurditas terdapat pada liriklirik yang dihimpun dalam 3 bait oleh Chairil Anwar. Lingkup absurditas yang dibahas sesuai dengan data temuan di lapangan ialah (1) manusia dan penderitaan, yang ditandai pada larik dipukul angin yang terpendam dan dan tahu, ada yang tetap tidak diucapkan, diksi yang dihadirkan memunculkan hipogram bahwasanya sang penulis menderita suatu hal yang tidak dapat diungkapkannya; (2) manusia dan tanggung jawab, yang ditandai pada larik $A k u$ sekarang orangnya bisa tahan, sudah berapa waktu bukan lagi, yang bukan dasar pertimbangan kini, tambah terasing dari cinta sekolah rendah, dan sebelum pada akhirnya kita menyerah, diksi yang dihadirkan memunculkan hipogram bahwasanya sang penulis merasa bahwa dalam hidup ini ada beberapa bentuk perlawanan yang harus padam dan seolah-olah membuat dirinya merasa seperti boneka takdir; (3) manusia dan kegelisahan, yang 
ditandai pada larik Cemara menderai sampai jauh, terasa hari akan menjadi malam, ada beberapa dahan di tingkap merapuh, tapi dulu memang ada suatu bahan, diksi pada larik-larik menghadirkan suasana bahwasanya sang penulis merasa seiring bertambahnya usia bertambah pula terasing dan lepas dirinya dari masa lalu; dan (4) manusia dan harapan, yang ditandai dengan Hidup hanya menunda kekalahan, diksi yang dihadirkan pada larik ini memunculkan suasana penerimaan yang absurd bahwasanya hidup mau tidak mau harus dijalankan dan dinikmati. Puisi Derai-Derai Cemara mengungkapkan kepasrahan dan ketabahan sosok aku, yang tidak lain adalah Chairil Anwar, dalam menghadapi kehidupan yang penuh dengan cobaan dan rintangan. Suka atau tidak suka, hidup harus dilalui dan dijalani dengan baik.

Berdasarkan hasil pembahasan, dapat disimpulkan bahwa puisi DeraiDerai Cemara mengandung nilai-nilai absurditas dan ketidakpastian. Sehingga dilakukan analisis bentukbentuk absurditas dengan pendekatan semiotika dalam puisi Derai-Derai Cemara yang mana berhasil mengungkapkan adanya nilai-nilai absurd dalam bentuk pemberontakan, ketidakmungkinan, penderitaan, kematian, dan kesia-siaan hidup. Hidup adalah sebuah perjalanan tanpa kepastian, semakin lama dijalani bukannya memunculkan banyak kebahagiaan melainkan terkikisnya harapan demi harapan. Ketika kematian adalah hal yang tidak bisa dihindarkan sedangkan harapan dan nilai tidak pernah menetap dan silih berganti, maka yang tersisa hanyalah kesia-siaan.

Dengan tulisan ini, kita dapat memahami bahwa sastra bersifat dinamis dan memiliki nilai-nilai yang dapat terus digali dalam kontribusinya dalam perkembangan pengetahuan. Terhadap puisi Derai-Derai Cemara karya Chairil Anwar ini bahwa sesungguhnya puisi ini memiliki nilainilai absurditas. Absurditas memberikan alternatif pandangan bahwasanya meskipun hidup terkesan akan berujung pada kesia-siaan, masih dapat dinikmati dan dijalani sepenuhnya. Untuk selanjutnya, puisi ini masih dapat dikaji dengan teoriteori lain untuk menggali aspek-aspek yang belum terpaparkan melalui teori absurdisme ataupun mendalami kajian ini dengan pendekatan semiotika terkhusus pada makna dan tanda-tanda dalam karya sastra. Penelitian ini dapat dijadikan referensi bagi para peneliti yang ingin meneliti dengan teori absurdisme ataupun meneliti puisi Derai-Derai Cemara karya Chairil Anwar menggunakan teori yang sesuai untuk menggali pesan yang belum tersampaikan.

\section{REFERENSI}

Adhitya, Tri. dkk. (2014). Aku-Lirik Religius dalam Antologi Chairil Anwar dan Kelayakannya 
sebagai Bahan Ajar. Kata: Bahasa, Sastra, dan Pembelajarannya, 2(1). Diperoleh 31 Juli 2021 dari http://jurnal.fkip.unila.ac.id/inde x.php/BINDO1/article/view/483 $\underline{1 / 3103}$

Aminuddin. (2002). Pengantar Apresiasi Karya Sastra. Bandung: Sinar Baru.

Anwar, Chairil. (2011). Aku Ini Binatang Jalang: Koleksi Sajak 1942-1949. Jakarta: PT. Gramedia.

Camus, Albert. (1999). Mite Sisifus: Pergulatan dengan Absurditas. Jakarta: PT Gramedia.

Endrawara, Suwardi. (2003). Membaca, Menulis Mengajar Sastra. Jakarta: Kota Kembang.

Fitri, Suci Amanda. Ibnu Wahyudi. (2013). Absurditas dalam Cerpen-cerpen Asneli Lutan. Skripsi dipublikasikan Fakultas Ilmu Pengetahuan Budaya. Universitas Indonesia. Depok. Diperoleh 31 Juli 2021 dari http://lib.ui.ac.id/naskahringkas/ 2016-04/S53355-

Suci\%20Amanda\%20Fitri

Keraf, Gorys. (2009). Diksi dan Gaya Bahasa. Jakarta : Gramedia Pustaka Utama.

Mohamad, Goenawan. (1982). Catatan Pinggir. Jakarta: Grafiti.

Noor, Redyanto. (2007). Pengantar Pengkajian Sastra. Semarang: Fasindo.

Oktiva, Nabila. (2018). Analisis Absurditas Surrealisme dalam Roman Villa Triste Karya Patrick Modiano. Skripsi dipublikasikan Fakultas Bahasa dan Seni Universitas Negeri Yogyakarta. Yogyakarta. Diperoleh 31 Juli
2021

dari

https://eprints.uny.ac.id/57176/

Pradopo, Rachmat Djoko. (1994). Prinsip-prinsip Kritik Sastra Cet. $V$. Yogyakarta: Gadjah Mada University Press.

Pradopo, Rachmat Djoko. (1995). Beberapa Teori Sastra, Metode Kritik, dan Penerapannya. Yogyakarta: Pustaka Pelajar.

Pradopo, Rachmat Djoko. (2012). Pengkajian Puisi. Yogyakarta: Gadjah Mada University Press.

Pribadi, Setia. Dida Firmansyah. (2019). Analisis Semiotika pada Puisi "Barangkali Karena Bulan" Karya WS. Rendra. Parole: Jurnal Pendidikan Bahasa dan Sastra Indonesia, (2)2. Diperoleh $31 \quad$ Juli 2021 dari https://journal.ikipsiliwangi.ac.id /index.php/parole/article/downlo ad/2737/pdf

Ratna, Nyoman Kutha. (2008). Teori, Metode, dan Teknik Penelitian Sastra. Yogyakarta: Pustaka Pelajar.

Setyawan, Arif. (2019). Chairil Anwar Service Literature Practices, 1942-1949. Aksis: Jurnal Pendidikan Bahasa dan Sastra Indonesia, (3)2. Diperoleh 31 Juli 2021 dari https://doi.org/10.21009/AKSIS. 030211

Sudaryanto. (1990). Metode Linguistik : Ke Arah Memahami Metode Linguistik. Yogyakarta: Gadjah Mada University Press.

Sugiyono. (2015). Metode Penelitian Kuantitatif Kualitatif dan $R \& D$. Bandung: Alfabeta.

Sumardjo, Jakob. (1991). Pengantar Novel Indonesia. Bandung: PT Citra Aditya Bakti. 
Sumiyadi. (2010). Mazhab Sastra: Absurdisme. Jurdiksatrasia, FPBS UPI, (2)3. Diperoleh 31 Juli 2021 dari http://file.upi.edu/Direktori/FPB S/JUR.PEND. BHS. DAN SASTRA_INDONESIA/196603 201991031SUMIYADI/SUMIYADI/tentan g_drama_absurd.pdf

Utami, Dian Endah. (2018). Absurditas dalam Novel Sampar karya Albert Camus. Simki-Pedagogia, (2)3. Diperoleh 31 Juli 2021 dari http://simki.unpkediri.ac.id/mah asiswa/file_artikel/2018/5a9f6d5 d63330c38dde84c5b1f2c5662.p $\underline{\mathrm{df}}$

Werdiningsih, Endang. (2013). Pengembangan Kemampuan Berpikir Mahasiswa Melalui Pembelajaran Membaca Teks Absurd. Likhitaprajna: Jurnal Ilmiah Fakultas Keguruan dan Ilmu Pendidikan Universitas Wisnuwardhana, 15(1). Diperoleh 31 Juli 2021 dari https://likhitapradnya.wisnuward hana.ac.id/index.php/likhitaprad nya/article/view/75/70

Yusriansyah, Eka. (2019). Absurditas Naskah Drama "Pelajaran" karya Eugene Ionesco. Jurnal Sastra Indonesia, 8(2). Diperoleh 31 Juli dari https://journal.unnes.ac.id/sju/in dex.php/jsi/article/view/33715 